\title{
Arab Non-believers and Freethinkers on YouTube: Re-Negotiating Intellectual and Social Boundaries
}

\author{
Sebastian Elsässer (D)
}

check for

updates

Citation: Elsässer, Sebastian. 2021. Arab Non-believers and Freethinkers on YouTube: Re-Negotiating Intellectual and Social Boundaries. Religions 12: 106. https://doi.org/ 10.3390/rel12020106

Academic Editor: C. van Nieuwkerk Received: 1 December 2020

Accepted: 30 January 2021

Published: 5 February 2021

Publisher's Note: MDPI stays neutral with regard to jurisdictional claims in published maps and institutional affiliations.

Copyright: (C) 2021 by the author. Licensee MDPI, Basel, Switzerland. This article is an open access article distributed under the terms and conditions of the Creative Commons Attribution (CC BY) license (https:/ / creativecommons.org/licenses/by/ $4.0 /)$.
Seminar für Orientalistik, Christian-Albrechts-Universität Kiel, 24118 Kiel, Germany; elsaesser@islam.uni-kiel.de

\begin{abstract}
This article uses the increasing visibility of Arab non-believers in the virtual public sphere as an opportunity to re-examine the key issues and dividing lines between believers, sceptics, and non-believers in Arab societies. It analyzes the currently four most popular Arabic-language YouTube channels created by freethinkers, nonbelievers, and atheists and points out commonalities and differences in style, content, and message. The article argues that the sense of a lively and growing virtual community has raised the confidence of non-believers ( $(\bar{l}-d \bar{\imath} n \bar{\imath} y \bar{u} n)$ and atheists in the Arab world and made them more daring in their self-portrayal and in their demands on society. As the examples show, YouTube allows them to circumvent the hostility they face in society and in the mainstream media and to connect with an audience that numbers in the tens of thousands of people from all over the Arab world and the diaspora. The article argues that freethinking and non-belief imply an attempt to re-negotiate social and religious boundaries within Arab societies and could-in the long run-have an impact on legal and constitutional questions as well, such as family law and the prerogatives of religious authorities.
\end{abstract}

Keywords: nonbelievers; freethinkers; atheism; Egypt; Syria; Arab world; social media

\section{Introduction}

Over the last decade, atheism and agnosticism have become more visible in the Arab

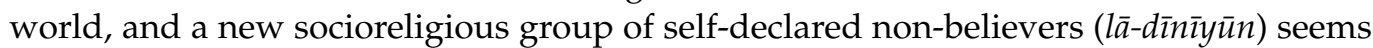
to be emerging (see the introduction to this special issue and several other contributions). While the phenomenon has been covered quite extensively in journalistic accounts, such as Brian Whitaker's Arabs Without God. Atheism and freedom of belief in the Middle East (Whitaker 2017) and Khaled Diab's Islam for the Politically Incorrect (Diab 2017), as well as in many articles in Arab-language blogs and newspapers, important analytical questions remain unanswered-for example, concerning the precise meaning and rhetorical function of the neologism $l \bar{a}-d \bar{\imath} n \bar{\imath} y a$ and to what degree it can even be considered a clearly defined intellectual trend.

Writing in the Oxford Handbook of Atheism (Schielke 2013), anthropologist Samuli Schielke pointed out that "atheism", the most common umbrella term to denote nonbelievers in a Western context, might be a misnomer in the contemporary Arab world, as the common Arabic word used in the sense of atheism, ilhād, does not necessarily imply an ontological stance on the existence or non-existence of God. Neither does the neologism $l \bar{a}-d \bar{\imath} n \bar{\imath}$, which simply negates belonging to a religion $(d \bar{\imath} n)$. This could mean that in the contemporary Arab context, "the dividing line between theism and atheism is often less important than one's stance towards other key issues of a religious worldview" (Schielke 2013, p. 639). Schielke suggests that, in order to reach contextually appropriate and precise definitions of the terms we are using, it is important to situate atheism and other shades of non-belief "within a wider landscape of moral-spiritual critique and dissent that is nearly as old as Islam" (Schielke 2013, p. 648).

This article uses the increasing visibility of Arab non-believers in the virtual public sphere as an opportunity to re-examine the key issues and dividing lines between 
believers, sceptics, and non-believers. Its aim is to provide an updated mapping of the self-positioning of Arab non-believers and their relationship with the wider field of religion and religious critique. For this purpose, I have examined the content of four YouTube channels propagating radical criticism of religion between 2015 and 2020, which I have selected based on to their relative outreach and popularity at the current juncture. ${ }^{1}$ While YouTube offers an infinite variety of content on almost any topic, the platform itself provides valuable quantitative data on the audience reaction to the published content, which makes it possible to identify the most popular and most widely known voices. To begin with, users can express their interest in a channel by "subscribing" to it, which means they will be notified about newly published videos. The individual videos of each channel can further be rated by the number of views and the number of likes and dislikes they receive. A large number of subscribers, a consistently high number of views for different videos, as well as high like-to-dislike ratios mean that a given YouTube creator has a dedicated and engaged audience. The four YouTube channels portrayed in this article (see Table 1) were among the leading Arabic-language channels according to these criteria in the past five years and, at the time of writing, have a core audience that numbers at least in the tens of thousands. Three of the four protagonists portrayed below are of Egyptian and one of Syrian origin, but that does not seem to limit their audience to people from the respective country. Additional user data, partly of a non-public nature and provided to me by one of the creators themselves, indicate that their channels are being watched all over the Arab world from the Maghreb to Egypt and the Arab East to the Arabian Peninsula, especially Saudi Arabia. ${ }^{2}$ They also have a strong following in the Arab-speaking diaspora in Europe and North America, where three of them actually live. In this sense, they really are manifestations of a regional and global trend of Arab non-belief.

Table 1. Popular YouTube Channels by Arab non-believers and freethinkers, December 2020.

\begin{tabular}{ccccc}
\hline Name of Channel & Hamed.TV & Sherif Gaber & Adam Elmasri & Kosay Betar \\
\hline Established in & May 2015 & March 2016 & October 2017 & February 2018 \\
No. of subscribers & 160,000 & 299,000 & 66,000 & 78,000 \\
Total no. of clips & 272 & 22 & 97 & 69 \\
No. of clips with over & 123 & 22 & 22 & 24 \\
100,000 views & 641,000 & $2,169,000$ & 290,000 & 266,000 \\
Most views for a single clip & & &
\end{tabular}

\section{Freethinking and Atheism in Arab Muslim Thought}

While atheism is a relatively recent phenomenon in the Arab world, radical religious criticism is not. A common term that has been used to describe the overlapping tendencies of unconventional religious inquiry, religious criticism, and skepticism in the Muslim world - past and present-is the term "freethinking" (Schielke 2013; Urvoy 1996; Coury 2018, p. 3; Stroumsa 1999). Freethinking means critical thinking about established religious dogmas and the total or partial rejection of established religious authorities. It does not necessarily imply either belief or non-belief in a given God or religion. Arab intellectual history before the modern era includes a number of radical minds who expressed far-ranging disapproval of all known religions of their time-Islam, Christianity, Judaism, Zoroastrianism, and Manichaeism - and many more figures who took issue with some religious dogmas from a rationalist or skeptical point of view (Urvoy 1996; Stroumsa 1999; Crone 2016). Stroumsa (1999) notices the vague use of the term "freethinkers" and proposes to reserve it for those who rejected all religious traditions, like Abū Bakr ar-Rāzī and Ibn ar-Rāwandī, the two protagonists of her study "Freethinkers of Medieval Islam" (Stroumsa 1999). While it is intriguing to know that Arab lā-dinn $\bar{s}$ - those who apparently

1 I have excluded some popular Moroccan channels from the survey because I do not understand Moroccan Arabic.

2 Adam Elmasri, video-interview with the author, 16 August 2020. Abdel-Samad speaks about his viewer statistics in the following clip from October (كلام جديد عن المخطوطات الاولى للقرآن :برنامج صندوق الإسلام ـ الحلقة الحادية والعشرون:2015. (Box of Islam Programme-21st episode: new talk about the first manuscripts of the Qur'an) https:/ /www.youtube.com/watch?v=CyOCQmE0WL0. 
"are not of a religion" — existed long before the term was invented (probably around the turn of the 21st century?), there is no benefit in defining freethinking in such a narrow way. Hence, I shall opt for a broader concept of freethinking that encompasses both believers and (possible) non-believers, precisely because it captures the "ambiguity and fluidity" (Schielke 2013, p. 648) of religious criticism in the Arab world that defies the application of narrow concepts.

Even though atheist ideas started spreading rapidly from Europe to the Middle East in the late 19th century and some Arab non-believers have adopted the term ilhād in the sense of "atheism" since the 1930s, self-declared non-belief remained a rare phenomenon in the Arab world throughout the 20th century. Nevertheless, the modern Arab world has a strong tradition of freethinking, which reached a first climax in the so-called "liberal age" between the 1920s and 1950s (Hourani 1962; Coury 2018). In this period, even some mainstream intellectuals, such as Ṭaha Husayn (1889-1973) and Nağib Maḥfūz (1911-2006), penned books that were considered highly impious by religious conservatives but have continued to inspire later generations of freethinkers (Diab 2017, pp. 282-86; Gunaym 2017). When the intellectual climate became more restricted and more conservative with the rise of authoritarian nation-states and, since the 1970s, of religious revivalism, many freethinkers became more cautious about voicing their views in public. Some decided to fight back against the rising tide of both oppositional political Islam and the Islamic-conservative turn of the nationalist regimes by adopting a discourse of political secularism ('almānīya) (Kinitz 2018). As a religious stance, secularism is a type of freethinking because it can be used to criticize dogmas and certain social and political effects of religion, but brackets the question of belief itself. On this background, the emergence of a broader trend of

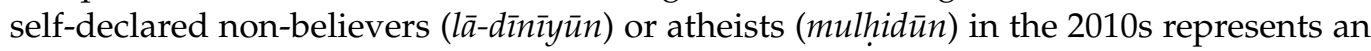
important rupture from the dominant pattern of the preceding decades. However, as this study is going to show, the emerging trends of non-belief overlap and intermingle with previous traditions of freethinking to a considerable extent.

Hence, for the sake of analytical precision, I will continue to use the term freethinking along with the terms non-belief and atheism. There is an overlap between freethinking and non-belief in the area where people profess that they "have lost their faith," "have left religion $x$," "do not believe that God communicated with any prophet," but do not explicitly declare themselves non-believers. The generic term for professed non-belief in the contemporary Arab world seems to be lā-dinniya. As mentioned above, its literal meaning is not belonging to any religion and does not imply a specific philosophical stance concerning God. In modern-day usage, ilh $\bar{a} d$ is a sub-category of non-belief that corresponds to what English-language scholarship usually calls "positive atheism" (Bullivant 2013; Keysar and Navarro-Rivera 2013). ${ }^{3}$ The new atheist writers of the English-speaking world, such as Richard Dawkins or Christopher Hitchens, are fairly well-known in the Arab world (Jackson 2018). However, many Arab non-believers prefer other terms to describe themselves, such as agnostic $(l \bar{a}-a d r \bar{l})$, indifferent $(l \bar{a}-i k r i t a \bar{t} \underline{t} \bar{l})$, or deist $(r u b \bar{u} b \bar{l})$. As the following analysis will show, these tendencies are significant in their own right.

\section{Arab Non-Belief and Social Media}

As Brian Whitaker, Khaled Diab, and other chroniclers of contemporary Arab nonbelief have pointed out, freethinkers and other non-conformist groups in Arab societies were early adaptors of the internet and the social media (Whitaker 2017; Diab 2017). The rapid spread of smartphones and the social media app Facebook in the Arab world has enormously facilitated this development. By the late 2000s, Atheist Facebook groups started springing up by the dozens-this is when observers first noticed that non-belief could be a growing phenomenon in Arab societies. The transition of some activists from the relatively closed and limited sphere of blogs and social media groups to YouTube

3 According to this definition, a positive atheist is someone who holds a specific belief that there is no God or gods, while a negative atheist is someone who does not know or does not care whether a God exists. 
represents a new stage in this development and a significant shift. Going out on a limb in this manner makes them more vulnerable but also tremendously increases their potential visibility and outreach. This shift cannot be explained by social media dynamics alone, but it is also embedded in wider social and political developments, especially in Egypt, where many of the YouTube activists come from.

After the Arab uprisings in 2011, mainstream media in the Arab world experienced a short-lived period of upheaval and experimentation (Abdullah 2014; Leihs 2015). In Egypt, television anchors in private satellite channels started addressing socially sensitive topics that had previously been considered out-of-bounds, including atheism. ${ }^{4}$ The young and media-unexperienced atheists who appeared on television shows usually faced a considerable degree of incomprehension and hostility in the studio. For the sake of spectacle, producers paired them with Azhari shaykhs who would attempt to interrogate them about their personal background and mental well-being and force them to admit intellectual and doctrinal errors (Diab 2017, pp. 260-64). In this context, it is not surprising that some activists, encouraged by the growing public interest in hard-hitting criticism of religion but intimidated by the hostile reception on mainstream television, turned to alternative media outlets. The first YouTube channel that managed to reach the production quality of regular television was Hamed.TV (Hamed.TV n.d.), set up by German-Egyptian political scientist Hamed Abdel-Samad (Hāmid ، Abd al-Ṣamad, b. 1972) in 2015, and a number of others followed in subsequent years.

\subsection{Hamed Abdel-Samad and the Freethinking Tradition}

In Germany, where Abdel-Samad has been living since 1995, he is a public intellectual known for his (self-)critical and often provocative engagement with Islam and his appearance in debates about the integration of Muslim migrants. It is little known there that he also runs one of the most successful Arabic-language YouTube channels covering freethinking and religious criticism. ${ }^{5}$ The channel was set up in May 2015 and had 157,000 subscribers as of August 2020. On this channel, Abdel-Samad has published a series of videos, mostly lectures by himself, entitled Șandūq al-Islām ("Box of Islam"), dozens of which have reached over a hundred thousand views.

Abdel-Samad was born and raised in rural Lower Egypt as the son of a village imam. After studying English and French in Cairo, he migrated to Germany, where he acquired an M.A. degree in political science and pursued a career in academia. In 2009, he published an autobiography entitled Mein Abschied vom Himmel ("My departure from heaven"), in which he portrays himself as an intellectually gifted and academically successful, but emotionally and sexually deeply troubled person. One of the main themes of the book is the desperate struggle of the first-person narrator with religion and faith. He is unable to find peace and fulfilment in religion but also cannot stop searching and hoping. "God is not the solution to my loneliness. God is my loneliness", he states enigmatically, adding that he envies people who can just calmly state that they "don't believe in anything" (Abdel-Samad 2010, p. 286). In Germany, this book propelled him from a little-known academic into a public figure. He appeared on television as a sidekick to famous journalist Henryk Broder in the satirical documentary "Entweder Broder-Die Deutschland-Safari" (2010/2011) and was invited to represent German Muslims in the advisory body "Deutsche Islam-Konferenz" by the German interior ministry.

In parallel, Abdel-Samad also attempted to launch a public career in Egypt. An Arabic version of his autobiography appeared in 2008 under the slightly modified title Wadāan ayyatuhā as-sama': riwāya ("Bye-bye, heaven-a novel"). Although he was well aware that the book was likely to cause furious reactions from religious conservatives and extremists

4 During this period, Aḥmad Harqān (b. 1982), a former Salafist from Alexandria, became a well-known face of atheism on Egyptian televisionsee for example his appearance on the show al-Bāb al-Maftūh, hosted by İmān Abū Ṭālib on Dream TV in June 2014. Available online: https: / / www.youtube.com/watch?v=QIVHoR_1C2g (accessed 4 February 2021).

5 https://www.youtube.com/channel/UCnTJcc901wCa5vZQQot8fCw/ (accessed 13 August 2020) 
and might put his safety at risk, he opted against using a pseudonym and personally appeared on Egyptian television to present the book (Abdel-Samad 2010, p. 296). His unconditional will to break taboos and stir up discussions runs deeply through AbdelSamad's intellectual and personal style. The documentary film Art War (2014) by Marco Wilms shows him in 2012-at the height of Islamist influence after the 2011 revolutionwalking through the streets of Cairo. He wears a T-shirt that features an image of Satan and the words (in English): "God is busy. How can I help you?" As one might expect, he ends up surrounded by a crowd of agitated young men but makes a narrow escape. In the tumultuous years of the Egyptian revolution, the courage and recklessness encapsulated in this anecdote earned him a great deal of respect from likeminded people and consolidated his reputation as a freethinker and fearless opponent of political Islam in Egypt. ${ }^{6}$ This partly explains the immediate success of his YouTube channel when it was set up in 2015.

The basic idea of "Box of Islam" is simple: Most of the clips, each between 22 and 30 minutes long, are plain lectures by Abdel-Samad on a given topic within the genre of historical criticism. Its gist is to treat sacred scriptures and sacred histories-like the Qur'an, the life of Muhammad and the early Muslim community-as simple human phenomena that can be analyzed with the same tools of historical investigation as any other event. Abdel-Samad's trademark approach is to draw on the scholarly discourses in which he is well-versed due to his religious formation in Egypt and years in German academia. He has a way of channeling high-brow academic debates into simple and provocative talking points. While his views about Islam and Muslims have often been criticized as one-sided and overly simplistic, he has always been able to justify them on the basis of commonly recognized textual readings and historical research. ${ }^{7}$

Some of the most important views that Abdel-Samad expresses in "Box of Islam" and in his books are the following: The Quran is not the word of God. "I do not believe that God ever talked to Muhammad or anyone else," Abdel-Samad states bluntly (Abdel-Samad 2015, p. 159). He argues that its content can only be salvaged from a modern scientific and ethical perspective if it is thoroughly demystified and humanized. The Qur'an should be read as a human document that reflects the circumstances of its time and the experiences of Muhammed and the early Muslim community (Abdel-Samad 2018, pp. 208-30). The spiritual and ethical message of the Quran remains a valuable source of inspiration for Muslim believers and can be appreciated by non-Muslims as well. The legislative part of the Quran contains rules that constituted creative and acceptable solutions to the practical challenges of the time but are no longer valid and certainly not applicable to modern multi-religious and democratic societies. This includes Quranic injunctions concerning war and peace, the treatment of non-Muslims, women, and sexuality. Quranic passages about heaven and hell are equally problematic and only acceptable if interpreted metaphorically in the way of the mystics.

According to Abdel-Samad, traditional and literal interpretations of the Quran lead more or less directly to what he labels "Islamic fascism" (al-fäšìna al-islāmīya). By Islamic fascism, Abdel-Samad means the political Islam of the Muslim Brotherhood and the Islamic Republic of Iran, as well as the Salafi movement. The choice of the term "fascism" shows Abdel-Samad's style of adding rhetorical flourish and acuity to common talking points, in this case criticism of political Islam. Rather than staying on conventional territory, Abdel-Samad ups the ante by claiming that "fascistic ideas" are already present in early Islam and in the Quran (Box of Islam \#36-43): Islam terminated religious pluralism on the Arab peninsula, demands absolute obedience from its followers, does not tolerate differing views, and aspires to world supremacy. Both Islam and fascism are "political religions" with their respective prophets, absolute truths, and propensity toward violence

6 Kacem El Ghazzali, “Kein Preis ist zu hoch für die Freiheit: Liberale Muslime kämpfen in ihren Ländern für sie, westliche Intellektuelle kapitulieren vor ihr", NZZ, 23 May 2019, https: / /www.nzz.ch/feuilleton/muslimische-welt-aktivisten-setzen-sich-fuer-die-freiheit-ein-ld.1483682. (El Ghazzali 2019).

7 For an academic criticism of Abdel-Samad's views see Mouhanad Khorchide's replies in the jointly published book Islam der Islam noch zu retten? (Abdel-Samad and Khorchide 2017). 
and martyrdom (Box of Islam \#36, 7:56). From the lens of cultural psychology, AbdelSamad claims, it is obvious that Muslim societies share the same symptoms of collective psychological disorder that plagued European societies in the age of fascism: narcissism, coupled with an acute inferiority complex and paranoia (Box of Islam \#36, 6:50). It is about time that Muslim societies acknowledge these problems and deal with them in a self-critical way.

It appears that this "psychological" approach is Abdel-Samad's favorite and most powerful tool of religious criticism. This becomes clear in his iconoclastic portrayal of the Prophet Muhammad, which is the subject of the first twenty episodes of Box of Islam, uploaded between June and October 2015. In the same year, Abdel-Samad published the book Mohamed. Eine Abrechung ("Settling the Score with Muhammad"), which covers the same material. In this book, Abdel-Samad initially shows an acute interest in revisionist tendencies in Western Islamic studies, which postulate that Islamic narratives about the Prophet and the early community cannot be corroborated scientifically and that early Islamic history may have to be retold in a totally different way. ${ }^{8}$ However, in the end, he opts for a radically different approach, which consists in taking the Islamic sources at face value, but reading them against the grain. This sudden shift away from radical historicalcritical skepticism is explained by Abdel-Samad's real aim, which is to draw a life-like "psychological portrait" of Muhammad that reflects his deeply personal disappointment in the Prophet.

Abdel-Samad's portrait goes as follows: Muhammad was a deeply ambiguous person who did a lot of good things but suffered from serious behavioral disorders and mental problems. The roots of Muhammad's torn personality lie in his difficult childhood. Orphaned at an early age and raised by strangers, he was an outsider in his own clan. Some even suspected that he was not a legitimate child. The deprivations of his early life, which only ended with his unconventional marriage to the wealthy widow Khadija, motivated his lifelong "addiction to power and recognition" (Abdel-Samad 2015, p. 16). His prophetical calling - after a relatively stable and happy period as Khadija's husband-was probably the result of a specific type of epilepsy. However, this was not his only illness: he was a narcissist, a control freak and a paranoiac. He compulsively married many women in his later life, but "he did not treat them like tyrant, but rather like a disturbed child that suffers from a fear of abandonment" (Abdel-Samad 2015, p. 16). Once he had tasted power as head of his community in Medina, his use of violence became unscrupulous and excessive even considering the standards of the time, as for example when he ordered the annihilation of a whole Jewish tribe, the Banū Qurayza (Abdel-Samad 2015, p. 192). Abdel-Samad further points out that according to the Islamic sources Muhammad condoned the killing of people who criticized him or made fun of him, for example the Jewish poet Ka $b$ b. al-Ašraf.

As much as Abdel-Samad's theses about Muhammad and the Quran and Islamic religion in general aim at provoking and unsettling devout Muslims and forcing them to embark on a radical re-evaluation of their beliefs, it is possible that his core audience does not perceive him primarily as a non-believer or atheist. To start with, Abdel-Samad has prudently never put a label on his own religious status: Is he a doubting and struggling believer who is just "angry at God and the Prophet" but willing to reconcile? Is he a religious searcher, a spiritual person without religion or God, like some of his German acquaintances whom he describes favorably in his autobiography? (Abdel-Samad 2010, pp. 17-36, 230-33) Or has he become an agnostic or an atheist? He does not say. Probably, "freethinker" would be a fair description. This also makes sense because it is precisely the tradition of Arab freethinking that allows him to be at the center of debates with people from a variety of intellectual and religious trends, many of whom seem to appreciate him as a critical interlocutor.

He rehearses the well-known works of Michael Cook and Patricia Crone on the subject, but seems more familiar with the writings of the "Saarbrücken school," a lesser-known group of German orientalists who share between them the hypothesis that the historical Muhammad probably did not exist and that Islam originated as a Arab-Christian sect in the Levant. In spite of devoting a great deal of attention to the revisionists, he ultimately dismisses their findings - which also have not been accepted widely in Western Islamic studies. 
Looking at the "guest list" of Abdel-Samad's channel, there is the Egyptian Ahmad Sa.d Zāyid, who appears in a series of episodes in 2019, is a university lecturer and fellow YouTuber who runs a popular channel on the "history of ideas" and calls himself a "humanist." In 2017, Abdel-Samad travelled around France and Morocco to meet a number of Maghrebian intellectuals and give them the opportunity to promote their published works. Among the people he interviewed are Muhammad al-Musayyah, a historian and researcher in pre-Islamic and early Islamic manuscripts,; secularist philosopher and Amazigh activist Muhammad ،Așīd, Rašīd Aylāl, author of an iconoclastic book about al-Bu ‘ārī and his Hadith collection ${ }^{9}$; and Sa $\mathrm{S} \overline{1} \mathrm{~d}$ Nāšìd, whose books promote a rationalist style of Islamic faith. ${ }^{10}$ Finally, there is Mouhanad Khorchide, professor of Islamic theology at the University of Münster (Germany), with whom Abdel-Samad has also held several public debates about "whether a reform of Islam is possible" and with whom he has published a common book on the same matter (Abdel-Samad and Khorchide 2017).

Significantly, none of these guests are professing non-believers and some, like Mouhanad Khorchide, Ahmad Sa'd Zāyid, and Sa ‘īd Nāšīd, are even avowed Sunni Muslim believers. Rather than the promotion of atheism, the main aim of Abdel-Samad's channel seems to be the creation of a virtual "intellectual salon" for freethinkers from all over the Arab-speaking world, including the Western diaspora. The aim that Abdel-Samad shares with his guests and that motivates them to collaborate with him is to demolish religious dogma and replace certainty with doubt and open inquiry - freethinking in its traditional sense. Finding an alternative identity and philosophical answers to existential questions outside religion, on the contrary, do not appear as a central issue. Regarding the age of Abdel-Samad and his circle of guests - uniformly middle-aged and above, this might be a message that has a stronger appeal among the older generations in the Arab world. However, regarding the size of the audience, it must be considered an important current alongside the novel trends of non-belief. It is also transformative in the sense that Abdel-Samad-if one accepts him as a freethinker-has probably pushed the boundaries of Arab freethinking as far as very few people before him. ${ }^{11}$

In one of their debates, Mouhanad Khorchide asks Abdel-Samad, somewhat exasperatedly, "I really wonder how you want to reform Islam if you at the same time hold that it is not susceptible to reform. Which kind of offer are you trying to make to Muslims? Burying the prophet and abolishing the Quran is not reform." While Abdel-Samad ducks the question, an increasing number of Arab activists on the internet-especially of the younger generation-have been offering a straightforward answer: leave Islam and become a $l \bar{a}$-dìn $\bar{\imath}$ (non-believer).

\subsection{Sherif Gaber: Atheist and Comedian}

According to his YouTube figures, the most successful creator of atheist content on the Arab internet in the late 2010s is Sherif Gaber (Šarīf Ğābir), a young Egyptian in his twenties, who has 288,000 subscribers (as of August 2020) and whose most popular videos have reached between one and two million views. While Hamed Abdel-Samad successfully boasts his academic credentials and erudition in the field of humanities and social sciences, the rising star of Sherif Gaber is attributed to his ability to translate religious criticism into the "language of the young people" or the "language of the streets." Another part of Gaber's fame lies in his courage-although living in Egypt, he appears under his real name-and his well-publicized history of persecution at the hands of religious conservatives and the Egyptian state. ${ }^{12}$ Even though his videos are exclusively in Egyptian Arabic, he has a circle of supporters from around the globe who provide his clips with

Șahịh al-Buhārī. Nihāyat usțūra ("Sahih al-Bukhari—the end of a legend”), Rabat: Dār al-Wațan, 2017.

10 An expression borrowed from title of one of his books: Dalīl at-tadayyun al- (āqil ("A Guide to rational religiosity"), Cairo: Dār at-Tanwīr, 2017.

1 For portraits of previous modern Arab freethinkers like Ameen Rihani, Ǧamīl Șidqī az-Zahāwi and Ma rūf ar-Ruṣāī̄ see Coury 2018.

12 Khaled Diab, "Egyptian atheists: Caught between Dr Jekyll and Mr Hyde", 24 May 2018, http: / / chronikler.com/reflections/egyptian-atheists-sherifgaber/. Sherif Gaber describes his own story in "Help Me Escape Egypt", 29 January 2019, https: / www.youtube.com/watch?v=QNXMBH5mIX0. 
subtitles in various foreign languages and have pledged a total of over USD 4000 monthly on the crowdfunding platform Patreon to support his effort. ${ }^{13}$

Remarkably, while most successful YouTubers tend to publish a new video every one to two weeks to keep the audience hooked, Gaber has only produced 22 videos since March 2016 (Sherif Gaber n.d.). What is it that makes him so interesting to his audience? Gaber's early videos follow the usual pattern of a YouTube lecture; with his informal style of talking and the heavy use of visual aids, cuts from documentary films, and memes, Gaber obviously appeals to a younger demographic of "digital natives" who expect a presentation to be entertaining.

While Gaber's talking points are similar to those of all non-believers (science, history, ethics, and logic), he somewhat stands out with a strong commitment to atheism (ilhia d) with a tendency toward scientism and materialism. In one clip, for example, he tackles the "superstition of the soul" and offers biological and chemical explanations to the phenomena of human feelings and consciousness. In a series of videos (March-July 2016), Gaber focuses on convincing the audience that it is not possible to reconcile a scientific worldview with Islam. In doing this he adopts a rhetoric of "shock" and "confrontation" (uslūb as-sadma), by which he juxtaposes his own rational, scientific, and humanist point of view to the conservative Islam of the traditional religious scholars and the Salafi preachers who populate Arab television. ${ }^{14}$ He especially attacks those who try to reconcile scientific discoveries with a conservative or scriptural reading of the Quran under the label of the "scientific miracle" (al-i, ğ $\bar{a} z$ al-ilm $\bar{\imath})$, a widespread exegetical tendency in contemporary Islam (Dallal 2004; Riexinger 2011; Bigliardi 2017). ${ }^{15}$ Like other non-believers on YouTube, Gaber is confident to be able to prove that the so-called "scientific exegesis" is in fact pseudoscientific nonsense. A favorite topic of Gaber's in the field of ethics is the subordination of women and sexual self-determination; he defends gender equality and the rights of homosexuals. He also attempts to prove that violence in the name of religion is not a problem of marginal extremists but goes back to the core teachings of Islam and have shaped the history of Muslim societies. The deeds of the Salafi-Jihadist extremists of the so-called "Islamic State," who controlled parts of Syria and Iraq between 2014 and 2017, are according to Gaber not an aberration from but a true reflection of Islamic law. ${ }^{16}$

What is unique about Sherif Gaber is the use of comedy and satire as a means of transporting the message of non-belief. In several short plays, Gaber stages fictitious conversations about religion in which he impersonates all characters. One video of this kind, "Secular or Islamic [state]?" features a bearded and turbaned Salafist, an average uneducated lower-class Muslim, a bigoted Coptic Christian, and a sophisticated upperclass intellectual discussing the notion of secularism. ${ }^{17}$ Another video called "A Muslim meets God on the Day of Judgement" (Muslim yuqābil Alläh fì yawm al-Qiyāma), ${ }^{18}$ is Gaber's most popular production so far with over two million views. Gaber impersonates an average, decidedly dumb-witted Muslim, whose confidence is not impaired by his limited knowledge about his religion. He has just died unexpectedly and now arrives at the gates of heaven. There he meets a bossy guardian angel and runs into trouble because the Judgement turns out to be different than he expects. For example, the angel has apparently

13 See https:/ / www.patreon.com/SherifGaber (accessed on 9 September 2020). Patreon is mostly used by artists and producers of creative internet content in order to invite donations and subscriptions by their audience. Although other YouTube activists of non-religion also use Patreon, Gaber so far seems the only one who earns a significant amount of money through it.

14 Deutsche Welle Arabic, Shabab Talk, 14.06.2016, https://www.youtube.com/watch?v=uLBwgBs6oZc, 28:22.

خرافة إعجاز تكوين الجنين في القرآن The fable of the miraculous scientific accuracy of the embryology of the Qur'an) 25 April 2016, https:/ /www. youtube.com/watch?v=qQXjyuxpNdE هل أوتاد الحبال إعجاز علمي؟ Are the "pegs of the mountains" a scientific miracle?) 2 May 2016, https: //www.youtube.com/watch?v=4IAPPvDs8qg.

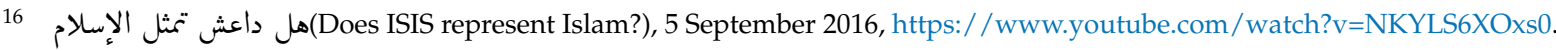

17 علمانية ولا إسلامية؟(Secular or Islamic?), 28 October 2016, https:/ / www.youtube.com/watch?v=db56vgzAsc8.

18 A Muslim meets God on Judgement Day) 28 January 2017, https://www.youtube.com/watch?v=s1AKpD49KmQ. 
never heard about the famous Hadith that whoever says "There is no God but God" will be allowed to enter paradise right away. Instead, he demands proof of good deeds.

A third video of the same type features two men trying to convince an atheist to join their monotheistic religion based on worship of the God "Renos" and his friend "Hamāda" (a common nickname for "Muhammad"). ${ }^{19}$ The conversation passes through the expected points of discussion between devout Muslims and non-believers. The atheist refuses to believe in a God whom nobody has ever seen and who cannot be described in rational terms. He suspects that the Prophet Hamāda might have written the Book himself, considering that nobody was there when he first received it and that parts of it read like an expression of his whims and desires. ${ }^{20}$ The believers then contend that the Book's beauty and wisdom proves its authenticity and has persuaded " 400 Russians and 67 North Koreans" to join the Religion. However, the atheist remains unimpressed and points out that the Book contains plenty of illogical and unscientific sentences. Next, the believers contend that atheism is a materialistic worldview that does not recognize any moral rules, while the atheist retorts that reason provides a sufficient foundation for morality. Finally, the discussion reaches the issue of creation. The atheist contends that the existence of the world does not logically presuppose the existence of a God who created it, even less so of a God who "loves and hates" like human beings.

Sherif Gaber's plays are open to interpretations on different levels. As any type of comedy and satire, they work with the tools of exaggeration and innuendo and play with the repressed emotions and taboos of the audience. ${ }^{21}$ The open blasphemy involved Gaber's portrayal of the Judgement Day and the "Renos and Hamāda" parody is a tool of provocation that has much in common with Abdel-Samad's irreverent portrayal of the Prophet, but the theatrical enactment gives it an additional edge. Gaber's believing critics-who are at least as numerous and vocal as his supporters-correctly point out that the religious types he impersonates and the things they say about religion are grotesque caricatures that do not represent a deeper understanding of Islam. ${ }^{22}$ Indeed, one might question whether Gaber's stark juxtaposition of various figures representing his own atheistic point of view and a parade of devout morons and bigots can deliver an intellectually compelling criticism of Islam as such. Needless to say, the atheist always easily wins the argument.

On a different level, Gaber's satire can also be read as a biting commentary on socially existing religion, in which case it becomes hard to deny that his figures-however exaggerated-are taken from real life in Egypt and the Arab world. People like them can be witnessed in religious debates on television on a frequent basis, and they constitute a constant source of anxiety for Arab non-believers who are considering to "come out" about their non-belief. ${ }^{23}$ On this background, they can easily relate to the scenes enacted by Gaber. For the non-believers who make up his large group of fans and admirers, Gaber's plays have a potential of catharsis and self-assurance: First, they allow them to have a good laugh about social situations that are filled with awkwardness and anxiety in their own imagination or experience. Second, they symbolically reverse the balance of power, which is heavily tilted in favor of the religious conservatives in real life (Jackson 2018; Diab 2017, pp. 244-93; Whitaker 2017; Schielke 2013, p. 647). In Sherif Gaber's parallel universe, the atheist confidently deflects the arguments and threats of the believers and proves his own

19 . شيخ يدعو ملحد إلى عبادة الإله (A sheykh calls an atheist to the veneration of a deity) 19 February 2018, https://www.youtube.com/watch?v=mG6 4EUUxOj4.

20 A somewhat distorted allusion to the story of Zaynab bint Ğahš, which is frequently mentioned by Arab non-believers, cf. (Abdel-Samad 2015, pp. 127-32). According to the Quran (Q 33:37), God personally decreed Muhammad's marriage to Zaynab, thereby changing the rule that Muslims could not marry the former wives of their adopted sons.

21 For a more detailed analysis of the use of humour among Arab atheists, see the contribution of Lena Richter in this special issue.

22 For example, Ahmad Buhayrī. شيخ يدعو ملحد إلى عبادة الإله الواحد (07) (!عرفوه بالعقل "Know it with your intellect” (7) A sheykh calls an atheist to the veneration of a deity). 24 March 2018 https:/ /www.youtube.com/watch?v=KklifQdSjKA.

23 According to numerous accounts collected by journalists, non-believers face hostile reactions from relatives, friends, and acquaintances on a daily basis, and many more have probably been choosing to keep their real convictions to themselves. See (Jackson 2018; Whitaker 2017, pp. 77-98; Diab 2017, pp. 244-93). 
intellectual and moral superiority. Even Heaven is on the side of the non-believers: In the Judgement Day scenario, it turns out that God has just been watching a video of Carl Sagan, an American science popularizer with avowedly naturalist and agnostic convictions-and He enjoyed it greatly! ${ }^{24}$

\subsection{Adam Elmasri: A Deist Alternative to Atheism?}

While the shock-and-confrontation style of Hamed Abdel-Samad and Sherif Gaber is probably one of the keys to their social media fame, there are other paths to success as well. On the basis of the well-known accounts of Arab Atheism, the Egyptian Adam Elmasri (a pseudonym), may appear as a rather untypical Arab non-believer. He was not born into Islam, but into Coptic Christianity, and he does not declare himself an atheist (mulhīd), but describes his own beliefs as deist $(r u b \bar{u} b \bar{\imath})$. Since the start of his YouTube channel in October 2017 , he has been able to gather an audience of over 60,000 subscribers, and more than a dozen of his videos have crossed the threshold of 100,000 views. Thousands of favorable comments and questions under his videos also reveal that his message motivates a high degree of engagement among his audience.

From his videos, it is possible to put together a fairly detailed intellectual and religious biography of Adam Elmasri. Doubtless, Adam's ability to verbalize and explain the complex intellectual and emotional process of becoming an unbeliever is one of the strengths of the channel. Adam was born in the late 1970s in Cairo and grew up in Egypt as a Coptic Orthodox Christian. ${ }^{25}$ He describes his former self as a committed believer who enjoyed mass and spiritual retreats at monasteries (a common practice among Coptic Orthodox believers) and lived his daily life "in the company of Jesus Christ." As an adolescent, he became engaged in religious dialogue and acquired a great deal of knowledge about Islam through reading and attending discussion groups with Muslims. He graduated from college in Egypt and worked for a while as a graphics designer. Adam's departure from Christianity only occurred after he migrated from Egypt to a Western country at the age of $27 .{ }^{26} \mathrm{He}$ had already reached his thirties when, after enrolling in a humanities-based BA program of Biblical Studies, he came to realize that "religions are just a human invention and that there is no such thing as revelation." Adam describes his departure from religion as intellectually liberating-stressing the enlightening effect of philosophical reasoning and scientific knowledge-but also as emotionally painful.

In several videos, Adam explains why rejecting religion has not turned him into an atheist stricto sensu. He describes himself as a $l \bar{a}-d \bar{\imath} n \bar{\imath}$, someone who does not follow any religion, and a deist $(r u b \bar{u} b \bar{\imath})$, a believer in some sort of "first mover" (musabbib awwal) or creating force (quwa haliqa). ${ }^{27}$ Some of his educational videos describe Adam's open-ended search for alternative philosophical ways of thinking about God. ${ }^{28}$ A major reference seems to be the best-selling "Conversations with God" series by American author Neale Donald

24 . مسلح يقابل الله يوم القيامة. (A Muslim meets God on Judgement Day) 28 January 2017, https://www.youtube.com/watch?v=s1AKpD49KmQ, 13:40. 6qFhA; فيديو لابد من مشاهدته لكل مسيحي ترك الإيمان او يعرف شخصاً ترك المسيح. (A must-watch video for every Christian who left belief or knowns anyone who left Christ), 20 September 2018, https://www.youtube.com/watch?v=HwHukFZbUEs In Seven Years—a comment on the journey of some atheists and why they ended up with atheism), 11 February 2019, https:/ / www.youtube.com/watch?v=0MByY2ilG08. Adam Elmasri, video-interview with the author, 16 August 2020. كيف تعجز الحجة الأخلاقية عن إثبات وجود الله How the moral argument for the existence of God falls short), 25 February 2020, https:/ /www.youtube. com/watch?v=fWhj_m5-dnU.

28 At the beginning of his YouTube career, he used the pseudonym al-bāhit ("searcher"), probably a deliberate double-entendre between the two meanings of the Arabic term baht: religious-spiritual search and scientific research. 
Walsch, who is considered a representative of New Age or non-religious spirituality. ${ }^{29}$ Quite different in style are a number of carefully produced "short films" that highlight the emotional, personal side of non-belief and the search for answers to existential questions. ${ }^{30}$ Considering the effort that must have gone into them, they seem to be closest to Adam's heart and personal aspiration. However, regarding the number of views and comments, his audience clearly prefers Adam in his role as a hard-hitting, witty and academically informed critic of religious dogma.

Most of his videos, as well as his most popular ones fall into this category. Their general style is that of an educational lecture, but Adam Elmasri's eloquent rhetorical style and consistent use of colloquial Egyptian Arabic also inspire a degree of informality. Adam's videos are split between those attacking specific Christian and Islamic dogmas, such as the resurrection of Christ or the inimitability of the Quran, and those that criticize teachings that are in some way common to Islam and Christianity. Adam's treatment of Christianity is clearly focused on the Egyptian context and goes right to the core of the most commonly held religious beliefs and practices among Coptic Orthodox Christians (Voile 2004; Heo 2018). In one of the first videos of this kind, he challenges the claim of the Coptic Orthodox Church that it has preserved the authentic original doctrine of Christianity. He describes the large variety of Christian teachings from the very beginning and argues that, from a scientific point of view, there is no such thing as the original Christian doctrine. ${ }^{31}$ Even the compilation of the Gospel, he argues, was subject to a great deal of historical accident. Subsequently, Adam Elmasri published a series of clips that challenge and debunk "Christian miracles": the widely celebrated Marian apparitions in Zaytūn (1968) and in other places across Egypt; the Holy Fire miracle experienced by Orthodox Christians every year at the Church of the Holy Sepulchre in Jerusalem; miracles of healing attributed to the Virgin Mary or famous Arab Christian saints. ${ }^{32}$ In addition to this, Adam's channel also offers a series of more scholarly lectures on the history of Christianity.

While Adam originally started out with the aim of offering a rationalist and historicalcritical commentary on Orthodox Christianity and an introduction to non-belief, he quickly got drawn into the already raging YouTube rivalry between propagandists of Islam, mostly of the Salafi tendency, and Arab non-believers. His commentary on Islam was triggered by audience reactions and debates, rather than by a pre-conceived agenda. ${ }^{33}$ In his replies to viewers who welcome his radical criticism of Christianity and use it as an occasion to

29 (The illusion of separation-the biggest illusion in the history of mankind-this might change your life) 18 May 2018, https://www.youtube.com/watch?v=T0da6P6sn4k; (A journey within the mind of God—first episode—how does God communicate and how does he reveal himself?), 13 December 2018, https:/ / www.youtube.com/watch?v=1euaBn_VdHo. المؤمن الملحد ـ فيلم قصير عن الإيمان الصحيح

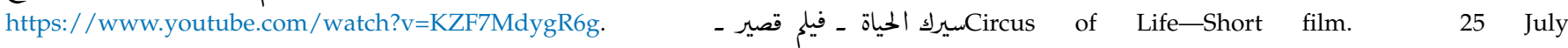
تجربة جديدة ـ مناجاة ـ لكل من يعاني في صراعه مع رحلة الشك للخروج من الأديان;2019. (A new experience-rescue for everyone who struggles with their journey of doubt towards leaving religions), 16 September 2019; https:/ /www.youtube.com/watch?v=MeFs0qB5i38.

31 (The greatest illusion in the history of early Christianity and the proprer apostolic/orthodox faith), 6 November 2018, https:/ / www.youtube.com/watch?v=C0vTg8kodW0;

32 كشف معجزات المسيحية ـ الحلقة الأولي ـ معجزة نقل جبل المقطم بين الواقع والخرافة/Wnveiling the miracles of Christianity—first episode—the miracle of the displacement of the Muqattam hills between reality and fable), 27 December 2018, https://www.youtube.com/watch? v=SfU73PA5cIE. كشف معجزات المسيحية ـ الحلقة الثانية ـ ظهورات العذراء، معجزة أم خداع؟ (Unveiling the miracles of Christianity-second episode-are the apparitions of the Virgin Mary miracles or deceit?), 17 January 2019, https://www.youtube.com/watch?v= pEbKhAJsT60. كشف معجزات المسيحية ـ الحلقة الثالثة ـ وهم النور المقدس خرافة سبت النور) Unveiling the miracles of Christianity—third episodethe illusion of the holy light on the 'Saturday of Light') 18 April 2019, https://www.youtube.com/watch?v=MdFm8BhD29E. كشف معجزات المسيحية ـ الحلقة الرابعة ـ معجزات الشفاء Unveiling the miracles of Christianity—fourth episode—miracles of healing), 4 September 2019, https://www.youtube.com/watch?v=DjZCEDk_F4w.

33 Adam Elmasri, video-interview with the author, 16 August 2020. 
"invite him to Islam," Adam goes much less into the details of everyday piety and mostly focuses on scientific mistakes and logical contradictions within the Quran. ${ }^{34}$

His favorite approach, however, consists in challenging shared dogmatic issues of the monotheistic religions, as well as social mores that are based on conservative interpretations of Islam and Christianity. This approach is especially significant, because it marks him out as a principled non-believer, whose message cannot easily be misconstrued as being just anti-Islam or anti-Christianity, a common misconception by social media users. ${ }^{35}$ Among the shared dogmatic elements in the monotheistic religions that Adam subjects to a historical criticism are the Deluge and the figure of Satan. ${ }^{36}$ As always, the message is they are in fact human inventions, "legends" (asātìir) and "illusions" (awhōm) that can easily be demystified with the tools of natural science and by historical-critical inquiry into the religious traditions themselves. In a series of videos entitled Rabbinā ayiz kiddah ("God wills it"), Adam discusses religious commandments pertaining to social and personal life: marriage and divorce, gender relations, love and sex, and homosexuality. He states, "My problem is not with religion in itself, but with those who claim to know exactly what God wants and want to force everyone to live accordingly." 37 Based on a general philosophical reasoning, he calls for gender equality in marriage and divorce and the acceptance of homosexuality as a biologically given inclination, not a choice, and argues that pre-marital intercourse should not be considered as "adultery" (zinā). Following up on the argument that the rules of the Sharia and Christian canon law are man-made and not sanctioned by God, he invites his viewers to imagine a God who "does not want us" to follow these rules, but only requires us to "live together in human kindness." 38

\subsection{Kosay Betar: Agnosticism and the Question of Coexistence}

A shared characteristic between Adam Elmasri (Adam Elmasri n.d.) and Kosay Betar (Qusayy Bìțār) (Kosay Betar n.d.), another emerging YouTube figure of the late 2010s, is the more nuanced approach towards belief and unbelief that does not construe them as polar opposites. Kosay is a Syrian in his twenties who lives in a Western country. He describes himself as a self-taught "agnostic" (lā-adrī) without any claim to philosophical or academic erudition. His videos consist in entertaining lectures and fictional conversations in colloquial Syrian Arabic. The self-description of his channel—as of August 2020—reads as follows: "Hello, I'm Qusay Bīṭār from Damascus, Syria. [ . . . ] I love and respect all humanist (insān $\bar{\imath}$ ) and moderate believers from any religion. The aim of my channel is to share my thoughts about religion, science and logic. It is an attempt to give the new generation a chance to see things from a different perspective, a chance that I did not have when I was young." ${ }^{39}$

Kosay started his YouTube channel in February 2018 and has published videos on an almost weekly base through 2019 and 2020. His audience has been increasing at a remarkable pace: Between February and August 2020, the number of subscribers to

34 In a nutshell: لماذا لم أعتق الإسلام ولم أعتبر بالقرآن (Why I did not embrace Islam and consider the Qur'an), 19 November 2018, https://www.youtube. com/watch?v=t4NQQyI_VdY.

35 Adam Elmasri, video-interview with the author, 16 August 2020. In a study on controversies about Islam on YouTube, Ahmed Al-Rawi (2017) notes that—across political and language barriers—-the YouTube audience is strongly polarized and divided into mutually antagonistic camps: Muslims vs. Western Islamophobes, Sunni vs. Shia Muslims, and Arab Muslims vs. Arab Christians. This explains why people would wrongly pigeonhole voices with a more nuanced or previously unknown message.

36 أسطورة الطوفان - إن كانت نظرية التطور خطأ فهل تصح الأديان والكتب السماوية؟ The legend of the Deluge—in case the theory of evolution is a mistake, does that mean the religions and their Holy Books are right?), 2 January 2020, https://www.youtube.com/watch?v=ug0-Pm-NZOE. (How the invention of the person of Satan/the devil developed and on its origin in the Abrahamic religions), 7 February 2020, https:/ / www.youtube.com/watch?v=MwZkjxGPN30.

37 ربنا عايز كدة ـ الحلقة الأولى ـ الزواج والطلاق (God does not want this—first episode—marriage and divorce), 25 October 2019, https:/ /www.youtube. com/watch?v=uqMifRoYfQo.

38 ربنا عايز كدة ـ الحلقة الأولى ـ الزواج والطلاق (God does not want this—first episode—marriage and divorce) 25 October 2019, https://www.youtube. com/watch?v=uqMifRoYfQo.

39 https://www.youtube.com/c/KosayBetar/about (accessed 25 August 2020). 
his channel rose from 30,000 to 60,000 , and many of his recent videos have passed the threshold of 100,000 views; thousands of likes and mostly favorable comments show that a considerable part of the audience is actively engaging with the content.

According to his own account, Kosay experienced a gradual loss of faith as a young adolescent that was triggered less by external changes than by lingering questions and doubts. ${ }^{40}$ Journalist Khaled Diab found a similar process in many of the non-believers he interviewed: "For a surprising number of atheists [ ... ] their abandonment of faith was, paradoxically, actually the product of an attempt to deepen it, understand religion better or silence the doubts plaguing their consciences." (Diab 2017, p. 255). Kosay turned to reading the Quran, hoping to find answers: didn't people always say that it was written in clear, easily understandable Arabic? Instead, he stumbled on many verses that were hard to understand and explain, and a great many that clashed with his own sense of logic and morality. As he was losing his faith more and more, he experienced a phase of shock, anger, and disappointment vis-à-vis his parents and Muslim society at large: Why were they telling us all those illogical stories about God, Creation, and Revelation? ${ }^{41}$ Why were they lying to us about the negative sides of the Prophet and the Quran?

As much as he stresses that he was not raised in an intolerant, bigoted religious atmosphere, Kosay expresses a strong intellectual disaffection with liberal and progressive interpretations of Islam. ${ }^{42}$ He compares those who argue that the Quran does not promote violence and hatred with those who propagate the "scientific miracles" found in the Quran: both approaches rely on selective and entirely arbitrary interpretations that have no philological or historical basis. When it comes to the questions of violence towards nonbelievers and the subordination of women, Kosay seems convinced that the conservative and extremist shaykhs do have much of the textual evidence on their side. He frequently uses "citations" in the form of short video clips from television shaykhs-all the way from the conservative Egyptian preacher Mutawallī Ša rāwi (1911-1998) to the league of mostly Saudi-Arabian and Egyptian Salafi scholars who became famous through television during the 2000s. One of his favorite references is Wağdī Gunaym (Wagdi Ghoneim, b. 1951), a firebrand preacher affiliated with the Egyptian Muslim Brotherhood who espoused Salafi-Jihadist views after the 2013 coup in Egypt. In the clips referenced by Kosay, he defends some of the most shocking practices re-introduced by the so-called "Islamic State" on the basis of traditional Islamic jurisprudence (figh), such as the enslavement of prisoners of war. ${ }^{43}$ Even though Kosay does not deny that different, more moderate interpretations of Islam exist and have a broad following, he mistrusts the broad influence of the "bigoted" (muta așsibūn) shaykhs in Arab societies, especially over uneducated people. It's the moral outrage at the injustice of both the foundational religious texts—Quran and Hadith—and the conservative scholars and preachers who uphold them to this and try to force them on society, that fuels Kosay's drive to dismiss the religious tradition altogether.

Kosay's attacks on religious dogma follow his personal explorations along the main paths of non-belief described above: textual criticism, philosophical reasoning, and historical inquiry. What is unique about his channel is Kosay's thoughtful engagement with a question that is probably quite essential to those who have lost their faith: What now? After deciding to leave Islam, where do I go? What does atheism even mean and what can non-believers contribute to society that believers can't? How do I counter accusations

40 الطريق إلى اللادينية - 7 المغالطون الحلقة (The deceivers \#7-the path towards non-belief), 8 August 2019, https:/ / www.youtube.com/watch?v=ITOs5

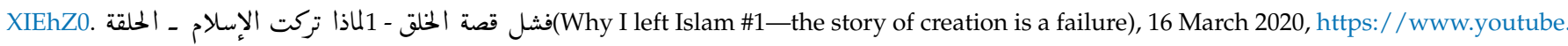
com/watch?v=fZMFZvKPjX4.

41 فشل قصة الخلق - 1لماذا تركت الإسلام ـ الحلقة) Why I left Islam \#1—the story of creation is a failure), 16 March 2020, https:/ / www.youtube.com/watch? $\mathrm{v}=\mathrm{fZMFZvKPjX4.}$

(The reasons for the spread of atheism and doubt in Islamic society一problems of exegesis), 5 May 2019, https:/ / www.youtube.com/watch?v=uc9xxsT9U40.

43 صالح لكل زمان و مكان - 12. Why I left Islam \#12-suitable for all times and places), 21 August 2020, https:// www.youtube. com/watch?v=5fYrCxLumdI. 
and prejudice? How do I sort out my relationship with believers, both intellectually and emotionally?

In one of his earliest videos, Kosay takes to task the arrogance and excessive ingroup/out-group thinking of many non-believers, especially recent ones: "Atheism does not make you more intelligent or more educated!" ${ }^{44}$ Some have left religion merely because of an emotional crisis or because it is "cool." ${ }^{45}$ Many atheists, he warns, have experienced a sudden, superficial and ill-digested conversion, which then becomes a source of intolerance and bigotry. Here, Kosay echoes (self-)critical tones that are not uncommon among Egyptian non-believers, too (Schielke 2013, p. 646; Andeel 2015). Kosay insists that atheists should be the first to respect others and other opinions because the lack of intellectual freedom inside religion is exactly why they left it. He suggests that being a believer or not is not a matter of intelligence ( $\left.\underline{d} a k \bar{a}^{\prime}\right)$ but of conviction $\left(i q t i n \bar{a} \bar{c}_{c}\right)$, and people with different convictions can still respect and love each other. Still, unbelievers have something important to give because they contribute to the spread of science and logic in societies that have been intellectually stagnant for a long time.

On a related note, Kosay points out that people who have left religion are still in search of a worldview and an ethical orientation that they find rationally convincing and emotionally appealing. ${ }^{46}$ The path toward settling on a new conviction can be long and arduous. For example, there is no teleological progression from religious belief to deism, then agnosticism, and finally positive atheism. Any of those stages is a valid intellectual stance in itself. Kosay stresses that is it important to explain these differences to religious believers as well, in order to counteract the problem that non-believers in Arab societies get lumped together indiscriminately under the label of atheism (ilhād), which is fraught with negative connotations. ${ }^{47}$ Kosay makes a lot of effort to confront the most common preconceptions and accusations faced by non-believers and to suggest effective counter-arguments.

For example, it is a common misconception (according to Kosay) that atheism and its emphasis on science leads to a materialist belief in the non-existence of God. ${ }^{48}$ In contrast, he proposes that non-believers simply place knowledge above belief and hence refuse to believe in things or theories that they do not find intellectually convincing, a stance called agnosticism (lā adrīya). When Muslim believers portray disbelief as something eccentric or implausible, it should be pointed out that disbelief is in fact quite a common thing: Most believers only believe in one particular God and disbelieve in all the other Gods that other humans believe in. Another common prejudice is the one that equates atheism with (supposedly) anti-religious modern ideologies such as communism or National Socialism and the crimes committed in their name. Kosay concedes that (unlike Hitler) Stalin and Mao were indeed atheists. However, he argues that what united Stalin and Mao and motivated their brutal methods was their "belief in the absolute power of the state." Political authoritarianism of this kind can be accompanied with a desire to abolish religion, but it can also be combined with a drive to control religion and use it as a tool of dominance, which according to Kosay is the case with the regimes of the Arab world. The most important point, however, is that different from any given religion, atheism is not a single doctrine with a fixed set of books or references. There is no atheist Book that constitutes the basis of the variety of ideologies and world-views adopted by non-believers.

44 انجازات الملحدين العرب(The achievements of Arab atheists), 19 April 2018, https:/ /www.youtube.com/watch?v=jYDIvv3Jgnw; Cf. the observation by Anthon Jackson: "Of course, there is plenty of in-group/out-group thinking on Egyptian atheist forums, including outright mockery of what many members see as pure religious lunacy." (Jackson 2018).

45 الطريق إلى اللادينية - 7 المغالطون الحلقة(The deceivers \#7-the path towards non-belief), 8 August 2019, https:/ / www.youtube.com/watch?v=ITOs5 XIEhZ0.

46 Ibid.

الإيمان و الإحاد و إحتمالية وجود الله Belief and unbelief and the probability of the existence of God), 5 December 2019, https:/ /www.youtube.com/ watch?v=_hpNTYZ20ig.

48 Ibid. 
A different but equally common accusation is that atheism is only a cover-up for the unbridled pursuit of carnal pleasure. ${ }^{49}$ According to Kosay, conservative believers like to picture atheists as people who migrate to the West in order live a life full of parties, alcohol, and sex. Here, he argues that they completely misconstrue a lifestyle that is in principle open to religiously prohibited pleasures like alcohol or premarital relationships. Why do they only focus on the sexual aspects of relationships and fail to recognize that they are as much about love, mutual respect, and responsibility? As matter of fact, there are many Muslims in Arab countries who pursue a hedonistic lifestyle; the pursuit of pleasure has nothing really to do with the question of belief and unbelief. For a man whose only concern in life is to give free rein to his sexual drive, the most appealing choice should not be any Western state but the Islamic system propagated by Salafi Muslim and in which men will be allowed to sleep with an almost unlimited number of wives and female slaves.

In one of his clips, Kosay states the view that, while non-believers will always be in a zero-sum struggle with the "bigots" (muta،aibunn) —among the learned authorities as well as among the common people-there is a chance that they can coexist and be on friendly terms with other Muslim believers. ${ }^{50}$ There are those educated Muslim who try to interpret the Quran in a contemporary way, who believe in a tolerant and forgiving God, and who want to live in peace with people from other religions. However, there are also uneducated Muslims who live with a simple belief in a good God and a desire to lead an ethical life, and there is no reason to be in conflict with them either.

\section{Discussion}

All of the freethinkers and non-believers covered in this survey are firm in their rejection of the sanctity of religious beliefs and dogmas and in their insistence that everybody should have the right to criticize them and even make fun of them outright. In the Arab world, where there is a long tradition of expressing doubt about religious dogma in a nuanced, allusive or figurative way, and in small and often 'elitist' social circles, this is a significant innovation. The deeper socio-economic reasons of this phenomenon remain to be explored: migration and the globalization of education and media, individualism and consumerism, the demographic transition and weakening of traditional family and neighborhood structures. The fact that the phenomenon also includes members of religious minorities seems highly significant in this context, but remains to be explored more thoroughly. However, there is no doubt that the apparent spread of freethinking and non-belief at this particular point in history has been made possible to a large extent by advances in media technology. Only the rapid spread of social media in the Arab world and the increasing availability of low-budget broadcasting technology have enabled a new generation of Arab non-believers to move beyond the limits of book-reading intellectual circles and beyond the hostile environment of the mainstream media and begin to address-in some cases apparently with considerable success-a wider Arabic-speaking public.

Beyond the general agreement on unlimited free speech concerning religion, there are important differences in style and intellectual approach. First, there is the differentiation in the protagonists' self-description: On the one hand, there are the non-believers who see themselves as atheists (Sherif Gaber) or use the more generic term lā-dinn $\bar{\imath}$ plus an additional qualifier like agnostic (Kosay Betar) or theist (Adam Elmasri). On the other hand, there are those who continue to identify with the religion they were born into or refuse to declare their religious status and form whom I have suggested the term freethinkers. If people in this group use self-descriptions, these do not indicate whether they are believers or not but focus on other aspects of their intellectual stance, such as secularism ( almānina), humanism (insānīya), and enlightenment (tanwīr $)$. Considering the case of Hamed Abdel-Samad, it

49 ترتد عن الإسلام لإتباع شهواتك؟ - 4أسئلة كلاسيكية (Typical questions \#4—do you apostasize to follow your desires?), 13 January 2020, https:/ /www. youtube.com/watch?v=2v1xnP_ren8.

50 لماذا تنتقد الإسلام فقط؟ - 8أسئلة كلاسيكية (Typical questions \#8-why do you only criticise Islam?), 17 February 2020, https://www.youtube.com/ watch?v=3aC4usVOAIY. 
seems likely that freethinkers find it easier to reach a degree of public acceptance and insert themselves into general debates, even if their criticism of religion is as radical as that of the non-believers. However, Abdel-Samad's apparent advantage over the other YouTubers in this area might as well boil down to his being older or being in possession of higher social capital as a successful academic and writer in a Western country. All things considered, it remains an open question if radical freethinking and atheism can benefit from their presence in the social media to become a more regular feature of public debates in the Arab world.

When it comes to the intellectual content and the type of arguments used, the distinction between freethinkers and non-believers is of less significance. All four channels delve into the four overlapping areas of critical thinking: natural science, textual criticism of the Holy Books, the history of religion, and philosophy (ethics and logic). The kind of mix depends mostly on the intellectual formation and preferences of the individual protagonists. Abdel-Samad relies mostly on his sphere of academic expertise, social sciences and history, plus textual criticism of the Quran and the Hadiths, while Sherif Gaber has the strongest focus on natural science-as mentioned he is the one closest to a 'materialist' conception of atheism. Adam Elmasri derives most of his input from historical and textual criticism, but has a much stronger philosophical side than the other channels.

There is also evidence of what Gavin Hyman has called the "reactivity" of atheist thought to the religious culture that it rejects (Hyman 2017, p. 29). The criticism brought forward against Islamic theology is focused very strongly on the scriptural meaning of the Quran and certain Hadiths and shows little interest in or in-depth knowledge of scholarly traditions. This is quite probably a reflection of the fact that literalist and fundamentalist interpretations have come to dominate popular knowledge of Islam in Egypt and the Arab world in recent decades (Schielke 2015, pp. 65-82). In addition, the most active opponents of the non-believers on YouTube are almost uniformly Salafi-styled activists who themselves contribute to directing the debate towards the exegesis of the foundational texts and excluding a large part of Islamic scholarly traditions. ${ }^{51}$

This circumstance explains why so many videos produced by non-believers deal with the hypothesis of the "scientific miracle(s)" (al-i,ğg$z$ al- $i l m \bar{\imath})$ of the Quran. This genre of religious reasoning, which claims that the Quran-if interpreted in the proper way-has predicted many scientific discoveries, is a common apologetic device in contemporary Islam that is popular across different religious schools and trends. As Sherif Gaber's imaginary "Renos and Hamāda" dialogue shows, it is often the first counter-argument used by Muslim believers if others question the truth of the Quran.

Another topic that is amplified by current events in the Arab world, namely the spectacular rise of Salafi-Jihadism in Iraq, Syria and some other countries torn by instability and civil war in the years after the Arab Spring, is the issue of Islam and violence. The surveyed YouTube channels frequently refer to the views and actions of the so-called "Islamic State" and its supporters as particularly shocking examples of religiously motivated violence. They also claim, based on the same scriptural sources that the Jihadists themselves use to justify their deeds (verses from the Quran and stories about the Prophet and his followers) that this is what the "golden age" of early Islam really looked like. In this way, Jihadism serves as an ideal foil for non-believers to confirm their rejection of Islam on intuitive moral grounds, sometimes at the cost of avoiding any recognition of less extreme theological readings.

Non-believers on YouTube cover similar topics based on current interest, argumentative convenience, or because they are challenged to do so by their opponents and critics, but these do not necessarily define their positive views or core message. There is a difference between explaining why you do not believe in certain things and defining what kind of non-believer you want to be. While Abdel-Samad's approach is mostly focused "demol-

51 On the polarization of online debates about Islam and the disproportionate influence of the more radical and extreme voices in either camp see Al-Rawi 2017. 
ishing" religion, the others also try to spell out a positive message of their own or even provide practical advice. The fact that they openly declare a divergent religious status that is far from self-explaining in the Arab world, already puts them under a certain pressure to spell out the intellectual and ethical consequences. While Sherif Gaber, Adam Elmasri, and Kosay Betar each offer a different world-view in place of Muslim and Christian theism, they remarkably converge on ethical and social questions. All of them strongly endorse gender equality and - a much more controversial issue in the Arab world-the acceptance of homosexuality. It seems that their non-belief comes as a package deal with "progressive" social views and offers the promise of an individualistic, cosmopolitan lifestyle.

An individualistic outlook also determines their views on how to deal with the vexing social and political situation in the Arab world, where freethinkers and non-believers still face widespread rejection and persecution (Whitaker 2017; Jackson 2018; Diab 2020). While the challenge of political Islam, both in its moderate and radical shapes, is too omnipresent to be ignored, Abdel-Samad is the only one who offers clearly articulated political views on current events in the Arab world. The other YouTubers portrayed here, on the contrary, avoid talking about politics almost completely. Their focus is, one might say, on strengthening their own intellectual community. They seem to believe that establishing a visible presence in the virtual public sphere is a step toward making non-belief an accepted part of the intellectual and social landscape in the Arab world. The sense of a lively and growing virtual community has certainly raised the confidence of non-believers and made them more daring in their self-portrayal and in their demands on society. In this sense, freethinking and non-belief imply an attempt to re-negotiate social and political boundaries within Arab societies at large. One crucial question for the period ahead is how religious authorities and institutions and common believers react to the challenge of non-belief and how believers and non-believers negotiate their relationship. However, recent studies about digital media in the Arab world caution us against over-estimating the potential of emerging digital communities when it comes to challenging and dislocating deeply entrenched social and political power structures (Richter et al. 2018, p. 4). It might be a long way before the voice of Arab non-believers will have an impact on legal and constitutional questions, such as family law and the prerogatives of religious authorities.

Funding: This research received no external funding.

Institutional Review Board Statement: Not applicable.

Informed Consent Statement: Informed consent was obtained from all subjects involved in the study.

Data Availability Statement: Not applicable.

Acknowledgments: I would like to thank Karin van Nieuwkerk, Lena Richter and the anonymous reviewers for valuable comments and suggestions.

Conflicts of Interest: The author declares no conflict of interest.

\section{References}

Abdel-Samad, Hamed. 2010. Mein Abschied von Himmel. Aus dem Leben eines Muslims in Deutschland. München: Knaur.

Abdel-Samad, Hamed. 2015. Mohamed. Eine Abrechnung. München: Droemer.

Abdel-Samad, Hamed. 2018. Der Koran. Botschaft der Liebe, Botschaft des Hasses. München: Droemer.

Abdel-Samad, Hamed, and Mouhanad Khorchide. 2017. Ist der Islam noch zu Retten? Eine Streitschrift in 95 Thesen. München: Droemer. Abdullah, Rasha. 2014. Egypt's Media in the Midst of Revolution. Carnegie Endowment Paper. July. Available online: https: / / carnegieendowment.org/2014/07/16/egypt-s-media-in-midst-of-revolution/hg1v (accessed on 25 January 2021).

Adam Elmasri. n.d. Available online: https:/ / www.youtube.com/c/AdamElmasri (accessed on 28 January 2021).

Al-Rawi, Ahmed. 2017. Islam on YouTube. Online Debates, Protests, and Extremism. London: Palgrave Macmillan.

Andeel. 2015. Mawlānā Miṣrī Mulhid" wa-mašyahat al-ilhād. MadaMasr. March 23. Available online: http://www.madamasr.com/ en/2015/10/25/opinion/culture/father-egyptian-atheist-and-the-sheikhdom-of-atheism/ (accessed on 10 September 2020).

Bigliardi, Stefano. 2017. The 'Scientific Miracle of the Qur'ān,' Pseudoscience and Conspiracism. Zygon 52: 146-70. [CrossRef]

Bullivant, Stephen. 2013. Defining 'Atheism'. In The Oxford Handbook of Atheism. Edited by Stephen Bullivant and Michael Ruse. Oxford: Oxford Univercity Press, pp. 11-21. 
Coury, Ralph. 2018. Sceptics of Islam, Revisionist Religion, Agnosticism and Disbelief in the Modern Arab World. London: IB Tauris.

Crone, Patricia. 2016. Ungodly Cosmologies, in Islam, the Ancient Near East and Varieties of Godlessness. Edited by Hanna Siurua. Leiden: Brill, pp. 118-50.

Dallal, Ahmad. 2004. Science and the Qur'ān. In Encyclopaedia of the Qur'ān. Edited by Jane Dammen McAuliffe. Leiden and Boston: Brill, vol. 4, pp. 540-58.

Diab, Khaled. 2017. Islam for the Politically Incorrect. London: Gilgamesh Publishing.

Diab, Khaled. 2020. Arab Atheists and their Quest for Acceptance amid Religious Intolerance. Rowaq Arabi. May 6. Available online: https: / / rowaq.cihrs.org/views-arab-atheists-and-their-quest-for-acceptance-amid-religious-intolerance (accessed on 4 September 2020).

El Ghazzali, Kacem. 2019. Kein Preis ist zu hoch für die Freiheit: Liberale Muslime kämpfen in ihren Ländern für sie, westliche Intellektuelle kapitulieren vor ihr. Neue Zürcher Zeitung, May 23.

Ġunaym, Rị̣ā. 2017. Mā hiya akțar al-kutub al- carabīya ta'tīran fī awsāṭ aš-šabāb al-lādīnīyīn al- carab? Raseef 22. May 14. Available online: https:/ / raseef22.net/article/103432 (accessed on 8 September 2020).

Hamed.TV. n.d. Available online: https:/ / www.youtube.com/channel/UCnTJcc901wCa5vZQQot8fCw (accessed on 28 January 2021).

Heo, Angie. 2018. The Political Lives of Saints: Christian-Muslim Mediation in Egypt. Berkeley: University of California Press.

Hourani, Albert. 1962. Arabic Thought in the Liberal Age, 1798-1939. Oxford: Oxford University Press.

Hyman, Gavin. 2017. Atheism in Modern History. In The Cambridge Companion to Atheism. Edited by Michael Marten. Cambridge: Cambridge University Press, pp. 27-46.

Jackson, Anthon. 2018. A Life of Pretending: Being Egyptian and Atheist. Quilette. April 17. Available online: https://quillette.com/20 18/04/17/life-pretending-egyptian-atheist/ (accessed on 9 September 2020).

Keysar, Ariela, and Juhem Navarro-Rivera. 2013. A World of Atheism: Global Demographics. In The Oxford Handbook of Atheism. Edited by Stephen Bullivant and Michael Ruse. Oxford: University Press, pp. 552-86.

Kinitz, Daniel. 2018. Die andere Seite des Islam. Säkularismus-Diskurs und Muslimische Intellektuelle im Modernen Ägypten. Berlin and Boston: De Gruyter.

Kosay Betar. n.d. Available online: https:/ / www.youtube.com/c/KosayBetar (accessed on 28 January 2021).

Leihs, Nadia. 2015. Persisting Powers, Financial Shackles and Political Polarisation. The Egyptian Media System in Transition. In New Media Configurations and Socio-Cultural Dynamics in Asia and the Arab World. Edited by Nadja-Christina Schneider and Carola Richter. Baden-Baden: Nomos, pp. 61-88.

Richter, Carola, Anna Antonakis, and Cilja Harders. 2018. Introduction. In Digital Media and the Politics of Transformation in the Arab World and Asia. Edited by Carola Richter, Anna Antonakis and Cilja Harders. Wiesbaden: Springer, pp. 1-8.

Riexinger, Martin. 2011. Islamic opposition to the Darwinian theory of evolution. In Handbook of Religion and the Authority of Science. Edited by James R. Lewis and Olav Hammer. Leiden: Brill, vol. 3, pp. 484-509.

Schielke, Samuli. 2013. The Islamic World. In The Oxford Handbook of Atheism. Edited by Stephen Bullivant and Michael Ruse. Oxford: University Press, pp. 638-50.

Schielke, Samuli. 2015. Egypt in the Future Tense. Hope, Frustration, and Ambivalence before and after 2011. Bloomington and Indianapolis: Indiana University Press.

Sherif Gaber. n.d. Available online: https:/ / www.youtube.com/c/SherifGaber (accessed on 28 January 2021).

Stroumsa, Sarah. 1999. Freethinkers of Medieval Islam. Leiden: Brill.

Urvoy, Dominique. 1996. Les Penseurs Libres Dans L'islam Classique. Paris: Flammarion.

Voile, Brigitte. 2004. Les Coptes d'Egypte Sous Nasser: Sainteté, Miracles, Apparitions. Paris: CNRS éditions.

Whitaker, Brian. 2017. Arabs Without God. Atheism and Freedom of Belief in the Middle East, 2nd ed. Scotts Valley: CreateSapce. 